\title{
Experimental evidence for pseudo- arrhenotoky in Hypothenemus hampei (Coleoptera: Scolytidae)
}

\author{
PHILIPPE BORSA* \& FINN KJELLBERG $\dagger$ \\ ORSTOM, Institut Français de Recherche Scientifique pour le Développement en Coopération, B.P. A5, Noumea, \\ New Caledonia and $\dagger$ Centre National de la Recherche Scientifique, Centre d'Ecologie Fonctionnelle et Evolutive, \\ B.P. 5051, 34033 Montpellier cedex, France
}

\begin{abstract}
Species breeding under local mate competition conditions have sex ratios biased towards females, a trait that is often associated with male haploidy (arrhenotoky). We used insecticide resistance as a genetic marker in Hypothenemus hampei, a local mate competing scolytid beetle that is cytologically diplo-diploid, for investigating the inheritance of nuclear genes. We confirmed that males express the resistance phenotype that they inherit from their mother, whatever their father. The segregation of resistance phenotypes in $F_{2}$ females significantly departed from the Mendelian model, and were in accordance with the arrhenotokous model, indicating that the parental genes were eliminated between $F_{1}$ and $F_{2}$. This finding (pseudoarrhenotoky) constitutes a step towards an understanding of the mechanism by which diplodiploidy evolves to arrhenotoky in local mate competing insects.
\end{abstract}

Keywords: breeding system, Hypothenemus hampei, insecticide resistance, local mate competition, pseudo-arrhenotoky, Scolytidae.

\section{Introduction}

Insects and mites for which matings occur between sibs before dispersal of the adult females, a condition known as local mate competition (LMC; Hamilton, 1967), have female-biased sex ratios. Breeding under LMC conditions is frequently associated with arrhenotokous reproduction (Hamilton, 1967; Wrensch \& Ebbert, 1993) whereby diploid females arise from fertilized eggs and haploid males from unfertilized eggs. Arrhenotoky provides an easy means to control sex and obtain highly femalebiased sex ratios, two traits advantageous for females of species breeding under LMC (Wrensch, 1993). A similar system, occurring in some species of mites is pseudoarrhenotoky, where the production of males requires eggs to be fertilized by sperm, but one set of chromosomes, supposedly the paternal one, is eliminated during development (Schulten, 1985) or at least is not transmitted to offspring. Pseudo-arrhenotoky also enables females to control the sex ratio of their broods although the underlying

*Correspondence: ORSTOM, UR 33 Zoologie, 911 avenue Agropolis, B.P. 5045, 34032 Montpellier cedex 1, France. mechanism is unknown (Sabelis \& Nagelkerke, 1993). In the following, arrhenotoky and pseudoarrhenotoky will be grouped under the term functional arrhenotoky. Functional arrhenotoky seems to have evolved independently at least seven to ten times in mites (Norton et al., 1993) and at least six times in insects (Wrensch \& Ebbert, 1993).

The scolytid beetles potentially offer an experimental system to study the mechanisms underlying the evolution of haplo-diploidy under LMC conditions (see Kirkendall, 1993). Inbreeding polygyny, whereby a few males fertilize all their sisters, has evolved repeatedly in scolytid beetles. This family seems to contain some of the few known diplodiploid species breeding under LMC conditions. These conclusions are, however, based on limited evidence (Kirkendall, 1993). One such species is Hypothenemus hampei, the coffee borer. It has the features of a typical local mate competing species. Females disperse after fertilization, laying eggs within a coffee bean where the progeny undergo complete development. The dwarf and flightless males undergo one fewer moult than females and mate with their sisters. In qualitative accordance with LMC theory, the sex ratio is distorted towards 
females in a ratio of about 10 to 1 , and this bias significantly decreases in offspring when the number of competing mothers increases ( $\mathrm{P}$. Borsa, unpublished data). The evidence for diplo-diploidy stems from karyological data (Bergamin \& Kerr, 1951; J. J. Stuart, unpublished data), from the observation that eggs laid by unfertilized females do not hatch (Bergamin, 1943; Giordanengo, 1992; Barrera Gaytan, 1994; but see Muñoz, 1989), and from nuclear DNA data showing the occurrence of heterozygosity in both females and a proportion of males (Borsa \& Coustau, 1995).

Recent data on resistance to endosulfan in $H$. hampei (Brun et al., 1995b) suggested, however, that males only express the resistance genes that were transmitted by their mother. Male progeny from crosses mother resistant $(\mathrm{R}) \times$ father susceptible $(\mathrm{S})$ were resistant and those from crosses mother $\mathrm{S} \times$ father $\mathrm{R}$ were susceptible. Their sisters in both cases showed a phenotype intermediate between those of the parents, i.e. response curves which were halfway between the susceptible and the resistant response curves on a log-probit scale. In this paper, in order to test how the resistance genes (here used as nuclear markers) are transmitted, we investigated the segregation of resistance phenotypes in $F_{2}$ offspring of $H$. hampei.

\section{Materials and methods}

Two laboratory $H$. hampei strains were used, resistant and sensitive, named $\mathrm{R}$ and $\mathrm{S}$, respectively. The $\mathrm{R}$ strain was derived from a sample of about 1000 fertilized females from Ponerihouen in New Caledonia, the only resistant $H$. hampei population known to date. It was inbred in the laboratory for 19 generations and subjected to selection by endosulfan insecticide in a standard test (Brun et al., 1991) every generation, with 100 to 1000 of the fertilized female survivors retained for the next generation. The $\mathrm{S}$ strain was derived from a natural sample of about 200 fertilized females from La Foa in New Caledonia. It was inbred in the laboratory for 15 generations. Every generation, 100-200 mothers were tested for endosulfan resistance and all proved susceptible. One hundred to 200 of their fertilized female progeny, not subjected to the test, were used for making up the next generation. The insects were reared on an artificial medium. Methods for rearing and diet composition are given in Brun et al. (1995a).

To obtain heterozygous $F_{1}$, female pupae from the $\mathrm{R}$ or $\mathrm{S}$ strains were removed from the rearing medium. They were then allowed to emerge and to mate with males from the opposite strain and to oviposit on diet. About 1 month later, $F_{1}$ female pupae were similarly removed, allowed to mate with the chosen $F_{1}$ males and to oviposit. Hence $F_{2}$ males and females of various pedigrees were obtained and they were tested for resistance when they reached the stage of fully developed, melanized adults.

The insecticide test was derived from a standard test on the basis of the concentration-mortality response data obtained in our laboratory (Brun et al., 1991; and unpublished data). Preliminary trials showed that a 200 p.p.m. endosulfan concentration in the test allowed us to discriminate between females according to their pedigree. Females from the $\mathrm{S}$ strain died before $6 \mathrm{~h}$ of exposure to insecticide (susceptible phenotype noted [S]). Females from the $\mathrm{R}$ strain survived after a $24 \mathrm{~h}$ exposure (resistant phenotype noted $[R]$ ). $F_{1}$ females from crosses mother $\times$ father $\mathrm{R} \times \mathrm{S}$ and $\mathrm{S} \times \mathrm{R}$ died between $6 \mathrm{~h}$ and $24 \mathrm{~h}$ of exposure (intermediate phenotype, [I]). Similarly, two phenotypic classes were defined for males: the [s] phenotype, exhibited by males of the $S$ strain and by mother $S \times$ father $R$ hybrids, both of which died before $6 \mathrm{~h}$ of exposure to 50 p.p.m. endosulfan in the test, and the [r] phenotype, exhibited by males of the $R$ strain and mother $\mathrm{R} \times$ father $\mathrm{S}$ hybrids, both of which survived after $24 \mathrm{~h}$. Increasing or decreasing endosulfan concentration or exposure time did not lead to the recognition of any intermediate phenotypic class for hybrid males.

We established the resistance phenotypes of $F_{2}$ progenies from various crosses among the $F_{1}$ obtained from the parental crosses mother $\times$ father, $\mathrm{R} \times \mathrm{R}, \mathrm{R} \times \mathrm{S}, \mathrm{S} \times \mathrm{R}$ and $\mathrm{S} \times \mathrm{S}$, giving $\mathrm{F}_{1}$ noted as $\mathrm{RR}, \mathrm{RS}, \mathrm{SR}$ and SS, respectively. All possible crosses among the $F_{1}$ were performed, except $\mathrm{RS} \times \mathrm{SR}$ and $\mathrm{SR} \times \mathrm{RS}$ because of an insufficient availability of SR and RS males. The offspring were then insecticide tested. Controls consisted of 85 males of the $\mathrm{R}$ strain, 56 males of the $\mathrm{S}$ strain, and females of the two strains and $F_{1}$.

Results of insecticide tests on $F_{2}$ females were compared with those expected under the Mendelian model, and under the functionally arrhenotokous model, whereby $F_{1}$ males only transmit the genes of their mothers to the $F_{2}$.

\section{Results}

The results of the insecticide resistance tests for $F_{2}$ males and females of $H$. hampei are given in Tables 1 and 2 , respectively. In accordance with previous results on $F_{1}$ males, in all crosses tested, $F_{2}$ males 
Table 1 Response to insecticide tests by Hypothenemus hampei male $\mathrm{F}_{2}$ from various crosses

\begin{tabular}{|c|c|c|c|c|c|c|c|}
\hline \multicolumn{5}{|c|}{ Cross among $F_{1}$} & \multirow[b]{3}{*}{$N$} & \multirow{2}{*}{\multicolumn{2}{|c|}{$\begin{array}{c}\text { Pheno- } \\
\text { types } \\
\text { in } F_{2}\end{array}$}} \\
\hline \multicolumn{2}{|c|}{ Female } & \multirow[t]{2}{*}{$x$} & \multicolumn{2}{|c|}{ Male } & & & \\
\hline mo & $\mathrm{fa}$ & & mo & $\mathrm{fa}$ & & {$[\mathrm{s}]$} & {$[\mathrm{r}]$} \\
\hline $\mathrm{R}$ & $\mathrm{R}$ & $x$ & $\mathrm{R}$ & $\mathrm{S}$ & 9 & 0 & 9 \\
\hline $\mathrm{R}$ & $\mathrm{R}$ & $x$ & $\mathrm{~S}$ & $\mathrm{R}$ & 4 & 0 & 4 \\
\hline $\mathrm{R}$ & $\mathrm{R}$ & $x$ & $\mathrm{~S}$ & $\mathrm{~S}$ & 10 & 0 & 10 \\
\hline $\mathrm{S}$ & $\mathrm{S}$ & $x$ & $\mathrm{R}$ & $\mathrm{R}$ & 10 & 10 & 0 \\
\hline $\mathrm{S}$ & $\mathrm{S}$ & $x$ & $\mathrm{R}$ & $\mathrm{S}$ & 8 & 8 & 0 \\
\hline $\mathrm{S}$ & $\mathrm{S}$ & $x$ & $\mathrm{R}$ & $\mathrm{S}$ & 10 & 10 & 0 \\
\hline $\mathrm{R}$ & $\mathrm{S}$ & $x$ & $\mathrm{R}$ & $\mathrm{R}$ & 8 & 2 & 6 \\
\hline $\mathrm{R}$ & $\mathrm{S}$ & $x$ & $S$ & $\mathrm{R}$ & 5 & 4 & 1 \\
\hline $\mathrm{R}$ & $\mathrm{S}$ & $x$ & $\mathrm{~S}$ & $\mathrm{~S}$ & 14 & 4 & 10 \\
\hline S & $\mathrm{R}$ & $x$ & $\mathrm{R}$ & $\mathrm{R}$ & 17 & 8 & 9 \\
\hline$S$ & $\mathrm{R}$ & $x$ & $\mathrm{~S}$ & $\mathrm{R}$ & 5 & 2 & 3 \\
\hline S & $\mathrm{R}$ & $x$ & $\mathrm{~S}$ & $\mathrm{~S}$ & 10 & 6 & 4 \\
\hline \multicolumn{8}{|c|}{ Controls } \\
\hline $\mathrm{R}$ & $\mathrm{R}$ & $x$ & $\mathrm{R}$ & $\mathrm{R}$ & 85 & 0 & 85 \\
\hline $\mathrm{S}$ & $\mathrm{S}$ & $x$ & $\mathrm{~S}$ & $\mathrm{~S}$ & 56 & 56 & 0 \\
\hline
\end{tabular}

Phenotypes [s] and [r], respectively, correspond to death before $6 \mathrm{~h}$, and survival after $24 \mathrm{~h}$ exposure to 50 p.p.m. endosulfan in the test.

mo: mother; fa: father; $N=$ sample size.

showed the phenotypes expected under the hypothesis that they only express their maternal genes.

For the $\mathrm{F}_{2}$ females, the Mendelian model was rejected in all cases, whereas the results were in accordance with the functionally arrhenotokous model (Table 2). From the series of controls it can be inferred that a small proportion (1.4 per cent) of the individuals were misclassified. Hence, scores of apparently aberrant individuals (i.e. those not expected under either Mendelian or functionally arrhenotokous models) were pooled with the next phenotypic class for calculating the $\chi^{2}$ as explained in Table 2. All except two of the unexpected phenotypes were individuals dying earlier than predicted suggesting the hypothesis of an experimental bias in the test. We nevertheless compared the proportion of unexpected individuals in crosses in which they could be explained by some transmission of genes from the parental grandfather with those in which they could not. There was no significant difference $\left(\chi_{1}^{2}, P>0.1\right)$ suggesting that the unexpected individuals were misclassified individuals and did not result from paternal genes being transmitted by sons.

\section{Discussion}

The present results are highly suggestive of functionally arrhenotokous inheritance of resistance to endosulfan in the scolytid beetle $H$. hampei.

The quality of the genetic marker is, however, crucial for assessing the regular mode of gene transmission within a species. A single autosomal nuclear gene presenting no epistasis should be used. Endosulfan is an insecticide of the cyclodiene family. In a number of insect species (ffrench-Constant et al., 1993; Thompson et al., 1993) including H. hampei (Borsa \& Coustau, 1995), resistance to cyclodienes is determined by a point mutation in the highly conserved $R d l$ gene, which is autosomal in Drosophila melanogaster (ffrench-Constant et al., 1993). Phenotypic data on resistance to endosulfan in $\mathrm{F}_{1} H$. hampei females (Brun et al., 1995b) are consistent with the typical genetic determination of cyclodiene insecticide resistance: codominant expression of a single-locus nuclear gene (Brown, 1967). All these results strongly support resistance to endosulfan being determined by a single codominant gene $(R d l)$ in $H$. hampei. The results of the crosses could, however, still be explained by the resistance gene being sex-linked (or sex-limited) rather than by functionally arrhenotokous inheritance. Nuclear DNA data (Borsa \& Coustau, 1995) showed that this is not likely: in some instances (4/38), the paternal $R d l$ gene was amplified in sons although sons do not express it. This would not have been observed had the resistance gene been borne by an $\mathrm{X}$ chromosome. The resistance character can therefore be considered an appropriate genetic marker for investigating the breeding system in this species of the scolytid family.

The results of the present experiments confirmed that paternal genes are not expressed in sons, but are in daughters. They also showed that in most cases, if not all, the paternal genes are not transmitted to $F_{2}$ females, in accordance with functionally arrhenotokous inheritance. Because males have been shown to inherit genes from both parents, as inferred from karyological data (Bergamin \& Kerr, 1951) and nuclear DNA data on a small proportion of males (Borsa \& Coustau, 1995) and indirectly suggested by some biological data (unfertilized eggs do not develop; Bergamin, 1943), we conclude that the paternal genes are somehow inactivated in sons and are not transmitted to the next generation. This type of breeding system, namely pseudoarrhenotoky (see Schulten, 1985), was unknown in beetles of the scolytid family, up to now believed to be either diplo-diploid or arrhenotokous (Kirkendall, 1993). 


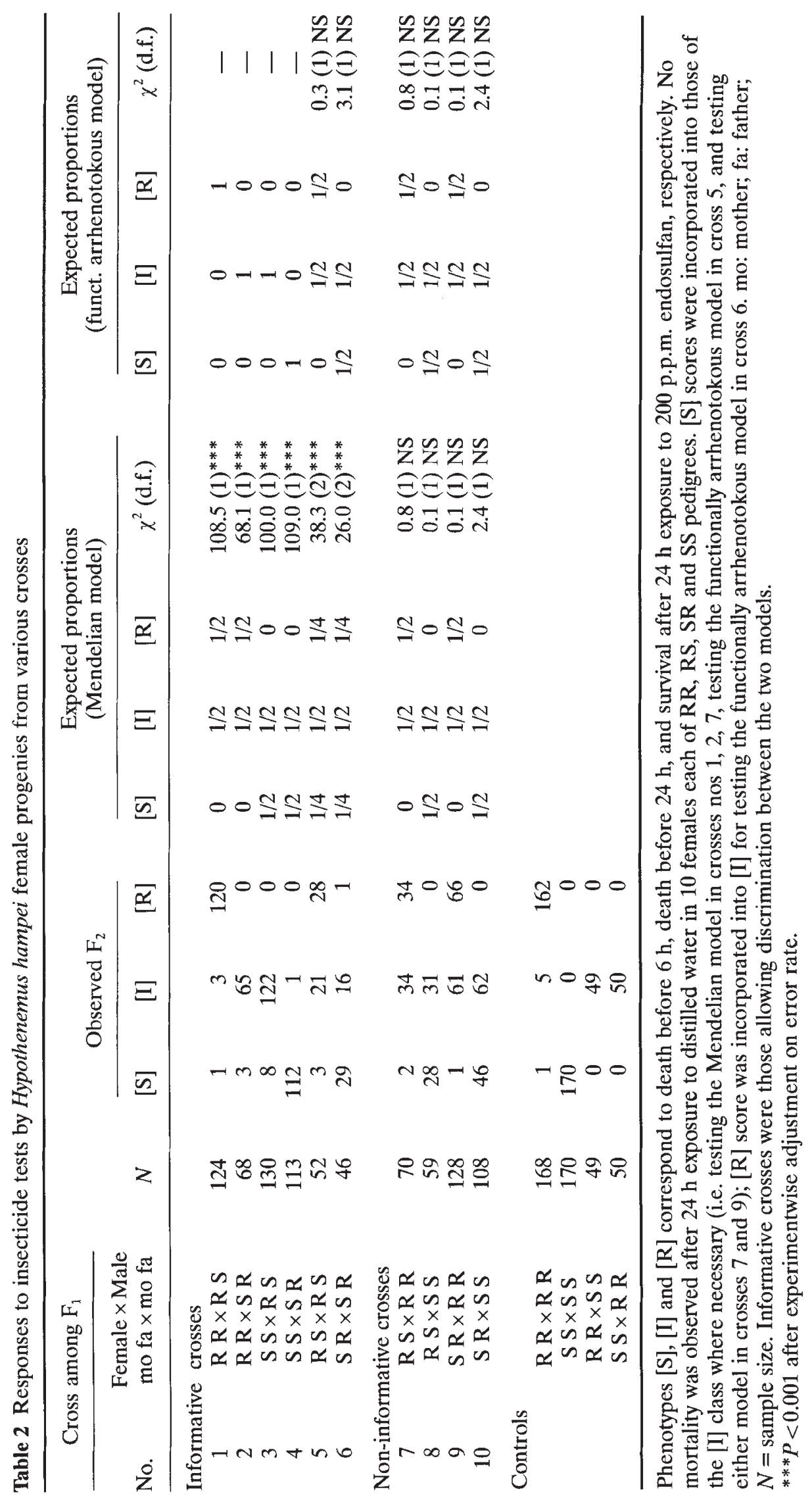

(c) The Genetical Society of Great Britain, Heredity, 76, 130-135. 
True arrhenotoky has been demonstrated in two lineages of the subfamily Scolytinae, Dryocetini and Xyleborini, in some species of which virgin females lay all-male broods (Kirkendall, 1993). Hence, according to the currently accepted classification of scolytids, the pseudoarrhenotoky observed here in $H$. hampei (lineage Cryphalini) would constitute a third independent origin of functional arrhenotoky in the Scolytinae.

The present results reinforce Hamilton's (1967) original idea that local mate competition and the ensuing female-biased sex ratios are correlated with functional arrhenotoky. It may even be questioned whether any species breeding under LMC is diplodiploid. Functional arrhenotoky is, however, not likely to be an obligate prerequisite for femalebiased sex ratios because, in a number of diplodiploid species, sex ratios in broods may vary in response to breeding conditions such as delay before mating (Werren \& Charnov, 1978). Although functional arrhenotoky may be an advantageous mode of reproduction for inbred species enabling a rapid selection on haploid genomes and easy facultative sex ratio adjustment, its origin is probably independent of these advantages. The repeated independent evolution of arrhenotoky or pseudoarrhenotoky in inbreeding species strongly suggests that a specific genetic process acts on sex determination under such conditions as hypothesized by Hamilton (1993). The presence of arrhenotokous and pseudoarrhenotokous species within the same subfamily is suggestive of a progressive passage from diplo-diploidy to pseudoarrhenotoky and finally to arrhenotoky. As the evolution of arrhenotoky has occurred several times in Scolytidae, it can be expected that investigating other species of the family or even withinspecies variation will provide intermediate cases between diplo-diploidy and the pseudoarrhenotoky observed in Hypothenemus and hence provide a key as to how haplo-diploidy actually arises.

\section{Acknowledgements}

L.-O. Brun kindly provided useful tips on insecticide testing and rearing techniques. We thank V. Gaudichon and C. Marcillaud for excellent technical assistance, and R. H. ffrench-Constant, D. P. Gingerich, M. Raymond, R. T. Roush, F. Rousset and J. J. Stuart for stimulating exchanges. We gratefully acknowledge advice and support from J.-B. Bergé, G. Fabres, F. Jarrige and ORSTOM MAA.

\section{References}

barrera gaytan, J. F. 1994. Dynamique des Populations du Scolyte des Fruits du Caféier, Hypothenemus hampei (Coleoptera: Scolytidae), et Lutte Biologique avec le Parasitoide Cephalonomia stephanoderis (Hymenoptera: Bethylidae), au Chiapas, Mexique. Thèse de Doctorat, Université Paul-Sabatier, Toulouse.

BERGAMIN, J. 1943. Contribuição para o conhecimento da biologia da broca do café Hypothenemus hampei (Ferrari, 1867) (Col. Ipidae). Arq. Inst. Biol., 14, 31-72.

BERGAMIN, J. AND KERR, W. E. 1951. Determinação do sexo e citologia da broca do café. Ciencia Cultura, 3, $117-121$.

BORSA, P. AND COUSTAU, C. 1995. Single-stranded DNA conformation polymorphism at the Rdl locus in Hypothenemus hampei (Coleoptera: Scolytidae). Heredity, 76, $124-129$.

BROWN, A. W. A. 1967. Genetics of insecticide resistance in insect vectors. In: Wright, J. W. and Pal, R. (eds) Genetics of Insect Vectors of Disease, pp. 505-552. Elsevier, New York.

BRUN, L.-O., MARCILlaUd, C., GAUDICHON, V. AND SUCKLING, D. M. 1991. Evaluation of a rapid bioassay for diagnosing endosulfan resistance in coffee berry borer, Hypothenemus hampei (Ferrari) (Coleoptera: Scolytidae). Trop. Pest. Mgmt., 37, 221-223.

BRUN, L.-O., GAUDICHON, v. AND COCHEREAU, P. 1995a. Techniques for individual rearing of Hypothenemus hampei (Ferrari) (Coleoptera: Scolytidae). J. Aust. Entomol. Soc. (in press).

BRUN, L.-O., SUCKLING, D. M., ROUSH, R. T., PREISLER, H., GAUDICHON, V. AND ROBERTSON, J. L. 1995b. Genetics of endosulfan resistance in coffee berry borer Hypothenemus hampei Ferrari (Coleoptera: Scolytidae): implications for mode of sex determination. J. Econ. Entomol., 88, 470-474.

FFRENCH-CONSTANT, R. H., ROCHELEAU, T. A., STEICHEN, J. C. AND CHALMERS, A. E. 1993. A point mutation in a Drosophila GABA receptor confers insecticide resistance. Nature, 363, 449-450.

Giordanengo, P. 1992. Biologie, Éco-éthologie et Dynamique des Populations du Scolyte des Grains de Café, Hypothenemus hampei Ferr. (Coleoptera, Scolytidae), en Nouvelle-Calédonie. Thèse de Doctorat, Université de Rennes I, Rennes.

HAMILTON, W. D. 1967. Extraordinary sex ratios. Science, 156, 477-488.

HAMILTON, w. D. 1993. Inbreeding in Egypt and in this book: a childish perspective. In: Wilmsen Thornhill, N. (ed.) The Natural History of Inbreeding and Outbreeding: Theoretical and Empirical Perspectives, pp. 429-450. University of Chicago Press, Chicago.

KIRKENDALL. L. R. 1993. Ecology and evolution of biased sex ratios in bark and ambrosia beetles. In: Wrensch, D. L. and Ebbert, M. A. (eds) Evolution and Diversity of Sex Ratio in Insects and Mites, pp. 233-345. Chapman and Hall, New York.

MUNOZ, R. 1989. Ciclo biólogica y reproducción parteno- 
genética de la broca del fruto del cafeto Hypothenemus hampei (Ferr.). Turrialba, 39, 415-421.

NORTON, R. A., KETHLEY, J. B., JOHNSTON, D. E. AND o'CONNOR, B. M. 1993. Phylogenetic perspectives on genetic systems and reproductive modes in mites. In: Wrensch, D. L. and Ebbert, M. A. (eds) Evolution and Diversity of Sex Ratio in Insects and Mites, pp. 8-99. Chapman and Hall, New York.

SABELIS, M. W. AND NAGELKERKE, K. 1993. Sex allocation and pseudoarrhenotoky in Phytoseiid mites. In: Wrensch, D. L. and Ebbert, M. A. (eds) Evolution and Diversity of Sex Ratio in Insects and Mites, pp. 512-541. Chapman and Hall, New York.

SChULTEN, G. G. M. 1985. Pseudo-arrhenotoky. In: Helle, W. and Sabelis, M. W. (eds) Spider Mites. Their Biology, Natural Enemies and Control, pp. 67-71. Elsevier,
Amsterdam.

THOMPSON, M., STEICHEN, J. C. AND FFRENCH-CONSTANT, R. H. 1993. Conservation of cyclodiene insecticide resistance associated mutations in insects. Insect Mol. Biol., 2, $149-154$.

WERREN, J. H. AND CHARNOV, E. L. 1978. Facultative sex ratios and population dynamics. Nature, 272, 349-350.

WRENSCH, D. L. 1993. Evolutionary flexibility through haploid males or how chance favors the prepared genome. In: Wrensch, D. L. and Ebbert, M. A. (eds) Evolution and Diversity of Sex Ratio in Insects and Mites, pp. 118-149. Chapman and Hall, New York.

WRENSCH, D. L. AND EBBERT, M. A. (eds) 1993. Evolution and Diversity of Sex Ratio in Insects and Mites. Chapman and Hall, New York. 